DOI: https://doi.org/10.31874/2309-1606-2019-25-2-5

УДК 1: 37.012.1

\title{
Крістоф Асмут
}

\section{Харківські лекції. Лекція 1. Фіхте і Шад - освіта як завдання ${ }^{1}$}

\section{Анотація}

У лекції обгрунтовується доцільність розуміння освіти як завдання, адресованого людині $i$ суспільству. Пов'язана з цим проблематика розглядається у сучасних соціокультурних контекстах, де актуалізуються філософсько-освітні

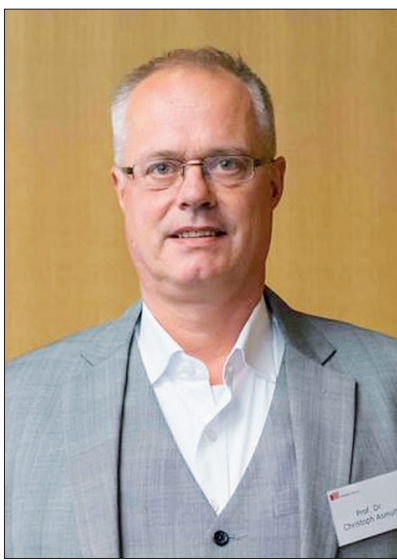
ідеї Фіхте і Шада. Розкривається зв'язок між політикою і освітою, встановлюються контекстуальні та історичні особливості цього зв'язку. Аналізуються тенденції розвитку сучасної освіти, позитивні і негативні наслідки дигіталізації та емпіричного повороту в освітній теорії і практиці. З’ясовується, що однобічна інтерпретація можливостей цифрових технологій обумовлена біологізаторським та прагматичним розумінням людини, що є наслідком радикальних змін у культурі та у світі праці. Становище людини у постіндустріальних реаліях і на початку XIX-го століття має спільні риси через відкриття нових можливостей для її самореалізації. Через це представники німецького ідеалізму приділяли особливу увагу освіті. Проблематика освіти у німецькому ідеалізмі пов'язана з ідеєю свободи і принципово новим розумінням людини, яка несе відповідальність сама за себе, а не покладається на метафізичну надбудову. Аналізуються смисли і функціональний потенціал кантівського категоричного імперативу, його антропологічне підгрунтя, де людина розглядається у ї̈ єдності з людством, що слід розуміти як самозобов'язання людини щодо людства $i$ самої себе. Ці ідеї набувають подальшого розвитку у Фіхте і Шада. Вони розглядають передумови перенесення свободи із теоретичної у практичну площину. Щоб свобода стала реальністю, людина мусить бути здатною діяти у матеріальній реальності, а для цього вона повинна мати артикульоване органічне тіло, здатне до формування. За Фіхте і Шадом, людина має існувати як жива істота, бути присутньою в екзистенції, залишатись собою, бути здатною включати у процес осмислення усю свою чуттєвість, розум $i$ розсудок, щоб не перетворитись на засіб для досягнення чужих цілей.

Ключові слова: освіта, німецький ідеалізм, свобода, людина, людство, мораль, органічне тіло, дигіталізація.

${ }^{1}$ Переклад з німецької мови М. Култаєвої . Лекція прочитана на семінарі «Німецький ідеалізм і сучасність: філософсько-освітні імплікації» 19.09. 2019 у Харківському національному педагогічному університеті імені Г. С. Сковороди з нагоди обрання професора Крістофа Асмута почесним доктором. 
Найкращі часи гуманітарної педагогіки вже позаду. Щоб визнати це, достатньо переглянути навчальні плани сучасних педагогічних інститутів. Там домінують емпіричні дослідження освіти, які зосереджуються на освітніх обладнаннях з їхніми носіями і покладаються на методи вибіркових кількісних показників з позитивними констатаціями. Та форма освіти, яку уявляли собі Йоганн Готліб Фіхте і Йоганн Баптіст Шад, ледь жевріє у своїй ніші.

Зв'язок між політикою та педагогікою завжди був дуже міцним і розлогим. Педагоги працювали і все ще працюють в амбівалентній близькості до політики. Тут можна спостерігати захоплюючу діалектичну гру. Спочатку це були філософи, саме вони намагались скористатись 3 політичних процесів. Передусім таке було в часи Фіхте і Шада. Згодом спостерігається зворотна тенденція: політика підпорядкувала собі педагогів. Ця діалектика в основному наблизилась до кінця. Замість колишньої взаємної інструменталізації сьогодні панує позірна політична нейтральність. Вона живиться об’єктивними науковими даними, кількісними і якісними вибірками. Або ж- положеннями нейробіології щодо розвитку і способу функціонування мозку.

При цьому педагогічні науки усувають з поля зору питання про людину. Справляється враження, що нібито визначальними для людини $є$ iї еволюція і біологія. Начебто людину можна збагнути через вимірювання, зважування і підраховування; начебто вона визначається через свою власну функцію. Людина зависає на помочах природи; а наука про людину заплуталась у тенетах природничих наук. За прикладами не треба далеко ходити. У Німеччині вже упродовж довгого часу триває дискусія про «дигіталізацію» ${ }^{1}$ шкіл. Вона була ініційована економічно орієнтованою педагогікою і міцно укоренилась у політиці. Політики хочуть, щоб учні мали компетенції користувачів комп'ютерів. Йдеться про їхню підготовку до професійного життя, яке широко дигіталізовано. Вони мають опанувати софтвер і користуватись ним. Було б чудово, якби вони навчились програмувати. Тим самим їм полегшується доступ до важливих ресурсів, засвоюються важливі компетенції, отже, робляться важливі кроки у їхній освітній кар'єрі. Тут переслідується за мету безперешкодний перехід до професійного життя. Учні, які навчаються у такий спосіб, мають колись успішно заповнити уявну карту професій, яка відповідатиме запитам цифрових технологій. ФРН виділила своїм федеральним землям на цей проект 5 млрд. євро. Це дуже багато грошей. Ця сума призначена для розбудови цифрової інфраструктури, отже

\footnotetext{
${ }^{1}$ Термін «дигіталізація» наводиться тут у його транслітерації з латини, а не на зразок Global English, тобто не як «диджіталізація, як це на жаль набуло поширення в України внаслідок експансії напівосвіти. У Німеччині від школяра до президента це слово вимовляється за правилами латини, що є європейським стандартом.
} 
гроші вкладаються у створення мереж та в їх обладнання. Але кожна федеральна земля, в свою чергу, додатково ще має сплачувати за рахунок податків педагогічні концепції і спеціальну підготовку учителів.

Наміри, які криються за цим дигітальним пактом, є зрозумілими. Зокрема зазначається: «Дигітальні системи та інструменти пронизують суспільство. Поступальний рух дигіталізації змінює світ праці. Безсумнівно, багато людей мають користь з дигітальних пропозицій, але при цьому вони часто-густо не розуміють прихованих за цим алгоритмів та комерційних моделей. Через це дигітальна компетенція має вирішальне значення для Кожної і Кожного, щоб вони були в змозі застосовувати дигітальні медіа самостійно та відповідально, а для суспільства - щоб воно було здатним підтримувати добробут і демократію у 21-му столітті». Постановка такої мети обумовлена ліберальними і економічними цілями. Ринок праці потребує дигітально компетентних і добре підготовлених найманих працівників. Водночас у політиці ширяє ідея, що тільки дигітальні компетенції в змозі забезпечити самовизначену участь у демократичних процесах.

Вихідним моментом освітньої політики є принципова індивідуалізація поведінки під час навчання. Це обумовлено високим ступенем культурної і соціальної багатоманітності школярок і школярів. На сайтах Федерального міністерства освіти і дослідження (BMBF) читаємо: «Для учениць та учнів, а також для учителів буде допомогою, якщо ми зможемо більш точно визначати індивідуальні поступи у навчанні і підкріплювати їх цілеспрямованим підбором цеглинок навчання і дидактичного матеріалу»². Учениці та учні повинні були звикати до того, що за їхньою працею встановлено спостереження і контроль. Звичайно. На це $\epsilon$ вагомі причини. Політика у сфері освіти припускає, що за допомогою дигітальних засобів зростуть перемереження між учнями у школі та поза школою. Тим самим нерівні стартові умови і соціальна занедбаність зможуть вирівнюватись краще і легше. Учні змогли б більш легко спілкуватись і обмінюватись на online-платформах. Більша частина шкільних завдань, як написано на сайтах BMBF, можна подавати більш спрощено і гнучко. Міністерство вважає, що учні будуть більш активно реагувати на нові медіа і тим самим матимуть більше інтересу до навчання на зразок симуляції ситуацій професійних викликів.

Ця тенденція розвитку зараз інтенсивно дискутується у Німеччині. Щоправда, ця дискусія здебільшого обмежується питанням як розподіляти гроші. Усе це нагадує гангстерську комедію, де вітер здуває банкноти у повітря, а усі перехожі намагаються заграбастати якомога

\footnotetext{
${ }^{1}$ https://www.bildung-forschung.digital/de/der-digitalpakt-schule-kommt-2330.html

${ }^{2}$ https://www.bildung-forschung.digital/de/der-digitalpakt-schule-kommt-2330.html
} 
більше грошей. Але щоб уникнути непорозуміння, я й надалі повторюватиму: навчатись користуванню комп'ютером сьогодні конче потрібно. Здобувати у цьому напрямку більше компетентностей не тільки бажано, а й необхідно. Більш або менш помірковане критичне ставлення до дигіталізації і ще гірше - відмова від неї не є відповіддю на виклики сьогодення. Критика техніки необхідна, але ворожість до техніки недоречна. Адже ми потребуємо ці технічні компетенції, щоб бути в змозі орієнтуватись у технічній цивілізації, яка стрімко змінюється. Відхилення техніки на зразок того, як це робив Гайдеггер у своїй промові про постав, вказує на нездатність зрозуміти, що їі можливості є внеском до емансипації людини. Отже, дигітальний пакт є дуже доброю ідеєю, яка спонукає також говорити й про інше. Те, що з моєї точки зору, тут є проблематичним, знаходить прояв, якщо звернутись до Йоганна Готліба Фіхте і Йоганна Баптіста Шада.

Багато у чому канун і початок XIX-го століття нагадує наш час. Це був час радикального прориву і перелому. Європейські суспільства переживали потрясіння, спричинені Французькою революцією. Наполеон змінив географію разом з юрисдикцією, церкви разом з конфесіями, структури панування разом з їхніми будівлями. Соціальна мобільність досягла незнаного доти рівня. Людина, що походила з незнатної корсиканської родини, змогла стати французьким королем. Відтепер було можливо сину ремісника стати європейським дипломатом, держслужбовцем або прусським професором. Стала реальною втеча з монастиря, щоб згодом розгорнути у Харкові просвітницьку діяльність у тільки-но заснованому університеті.

Ті часи відкрили можливість для появи особливих форм радикальних рефлексій. Фіхте і Шад, а також багато інших представників їхньої генерації, покладали великі сподівання на освіту. Вони просували емансипаторський образ людини, який живився філософією Канта. У своїй практичній філософії він розіграв козирну карту. Спочатку це була ідея автономії, самопокладання законодавства. Жодна вища інстанція, навіть божественна заповідь із Синайської гори, не повинна була упорядковувати людські справи і встановлювати мораль. Філософ з Кенігсбергу занадто добре знав, що минули часи теократії. Але якщо метафізична надбудова вже не здатна гарантувати значущість морального світу, то на що ще можна спиратись? Для Канта це було людство у власній та усякій іншій особі. Саме воно утворює серцевину категоричного імперативу. Людство не як людяність, а як самозобов'язання, як спрямоване на самого себе ядро автономної розумності, повинно було утворювати зобов'язуючу основу усіх моральних дій попри усяких там гетерономій. Будь у згоді із самим собою, з людством у Тобі, не супереч собі, коли Ти дієш. Уявляючи власну максиму як Свій Сам Собі встановлений загаль- 
ний закон, Ти зможеш перевірити, чи визначаєш Ти насправді Свою волю у згоді із Самім собою.

Водночас Кант пов'язав цю теорію зі ствердженням, що людина не може бути впевненою у моральності своєї дії на підставі самодослідження власної совісті. За Кантом, це унеможливлює будь-яку форму моральної пихатості. Саме ось цей останній аспект має більшого значення для поняття освіти як формування (Bildung).

Фіхте дотримувався кантівського обгрунтування моралі, вільного від метафізики, але зробив з цього висновок, що освіта як формування (Bildung) має спиратись не тільки на здатність людини бути самоціллю, бо для цього також треба приділити особливу увагу здатності людини до формування (Bildsamkeit). Без обгрунтування здатності до формування, не можна достовірно мислити освіту як формування. За усім цим у Фіхте приховується пристрасна полеміка 3 космологічним, а також моральним детермінізмом. Цей детермінізм є дуже схожим із сучасною, дуже поширеною науково-популярною точкою зору, за якою мислить, діє, навчається не людина, а її мозок, Фіхте сам на початку свого становлення як філософа мислив космос як вузол каузально-детермінованих процесів, що виключало людську свободу дії, а також здатність до формування. За його власним визнанням, саме критична філософія Канта звільнила його, Фіхте, від страхіття суцільного каузального детермінізму. Відтепер він запалав ідеєю свободи. У листі до Карла Леонгарда Райнгольда, свого попередника на професорській посаді у Йєні він написав відомі слова: «Моя система від початку до кінця - це тільки аналіз поняття свободи» ${ }^{1}$. Але поняття «здатність до формування» свідчить , що Фіхте продовжував роботу над поняттям образу, що сам себе формує, тобто створює. У специфічно модерний спосіб Фіхте коригує біблійне твердження, що Бог створив людину за власною подобою: Не Бог створює людину як образ у своїй подобі , а людина створює сама себе як образ, але не як пасивне наслідування попереднього вічного буття, а як самостворений образ, сформований так, як його вона його задумала. Позиція Гегеля у його «Лекціях до філософії релігії» та Фейєрбаха у «Сутності християнства» не відрізняються суттєво від ідеї Фіхте. Людина у Фіхте є свобідною також і саме по відношенню до Бога, який, за рішучим визначенням Фіхте, є нічим іншим, як основою морального світоустрою, отже, моральним законом, тобто категоричним імперативом.

Спочатку ця свобода ще $\epsilon$ цілком абстрактною. В «Основах загального науковчення» (1793/94) свобода $\epsilon$ порожньою автономією Я, що покладає само себе. Це трансцендентально-філософський конструкт, який переслідує лише одну мету - обгрунтувати правомірність застосування

${ }^{1}$ Fichte an Carl Leonhard Reinhold in Kiel, 8. Januar 1800, GA III, 4, S. 182 
нормативних і категоріальних понять. «Я», а разом з ним науковчення, передбачає дійсне діяння і знання. Для цього Фіхте розробляє реконструктивну дедукцію діючого кінцевого «Я». До умов, за яких взагалі можлива діюча свобода належать індивідуальність, природність і тілесність, які обгрунтовуються не в онтологічному, а у їх практичному вимірі і функції. На відміну від поширеною інтерпретації, Фіхте приділяє велике практичне значення саме тілесності. Моральний закон - це не просто формальний імператив; кінцеве Я не випадково має плоть і є організованою живою істотою з кінцівками. За Фіхте, тут йдеться про необхідний аргументований взаємозв'язок: щоб свобода отримала реальність, людина мусить спромогтись діяти у реальності з матерією і через неї, а для цього треба мати артикульоване органічне тіло. Для Фіхте верхівку аргументації становить те, що кожне «Я» водночас $є$ абсолютним «Я», отже, практичне завдання полягає у тому, щоб здійснити абсолютне «Я» у собі як емпіричне «Я». Відтак «Я» $є$ «Ми», ось так Фіхте переклав на філософську мову гасла революції: свобода, рівність, братерство.

3 цього виходить, що здатність людини до формування - це не тільки когнітивна справа. Здатність до формування торкається також й тілесності. Вчення Песталоцці про виховання, з яким Фіхте особисто познайомився у часи його домашнього вчителювання у родині Отт у Цюріху і який став його шанувальником, виходило з цілісної людини. Так само мислив і Фіхте. Він не створив інтелектуалістської теорії виховання, не говорячи вже про їі раціоналістичну версію , але запропонував філософію освіти, спрямовану на цілісну людину. При цьому він скористався з анти-дуалістичної загостреності своєї філософії, у якій концептуалізація «Я» здійснюється не через протиставлення тілу, а монадологічно. У його філософії немає безсмертної душі. Але замість цього є нескінченним завданням. Воно полягає у поступовому здійсненні розуму у світі. «Останньою метою як кожної окремої людини, так і усього суспільства, включно з усією працею вченого над суспільством, - наголошує Фіхте у ранніх «Лекціях про призначення ученого» (1794) - є моральне ушляхетнення цілісної людини. Це є обов'язком кожного ученого ставити собі цю кінцеву останню мету і постійно тримати ії перед очима в усьому тому, що він робить у суспільстві. Здатність до формування не позбавлена мети. У Фіхте вона за своєю структурою підпорядкована завданню суспільного удосконалення. Такі цілі не покладаються індивідуалістично, а ставляться у процесі подальшого розвитку суспільства.

У цьому напрямку мислить також Йоганн Баптіст Шад. Він стверджує: «Беззаперечно, людина є розумною істотою і приречена як така на свободу і самостійність, несумнівним є також й те, що вона повинна вирватись з кайданів неприхованої залежностіі наперед встановленого визначення усього того, що торкається її найвищої мети, і зробити саму 
себе усім тим, що наказує розум» ${ }^{1}$. Шад дотримується думки, що людина у дитинстві і юності попервах має формуватись під зовнішніми впливами, що виховання на самому початку означає становлення формування, яке поступово мусить визріти до «самодіяльності і самоформування». Задатки, необхідні для розгортання процесу само формування первісно закладені у людині, але вони потребують зовнішнього збудження. Як і Фіхте, Шад не мислив людину дуалістично. Він стверджував, що людина має свою органічну природу, яка полягає у «збуджуваності». Це стан здатності створювати образи, який чекає тільки на то, щоб перетворитись на динамічний процес формування. Через самопізнання виникає самоформування на основі «абсолютної, незалежної від усіх зовнішніх впливів життєвої сили. Отже, виховання є керівництвом до самокерівництва, емансипаторським підприємництвом, наприкінці якого знаходиться людина як автономна істота. Характер свободи, як зазначає Шад, - це «абсолютна незалежність від усіх чужих впливів і тому абсолютне самовизначення або само визначеність»². Правлячі сили вбачали у цій концепції вирішальну перепону. Переконання Шада були республіканськими. Завдяки новій філософії, яку поділяли Шад і Фіхте, одиничний ставав здатним усвідомлювати свою автономію, самовизначення замість феодального чужого визначення. Політична влада намагається підтримувати старі відносини релігійними забобонами і політичними репресіями. Але Шад впевнений: «Людина за допомогою абсолютної сили здатна подолати усі мислимі перепони, поставлені на шляху до їі високого призначення, якщо вона цього тільки захоче і вона повинна захотіти» ${ }^{2}$. Розум, в імені якого говорить Шад, є не безтілесною цілераціональністю, а цілісною людиною, яка проектує себе на ціле людство через своє самовизначення і самозобов'язання.

Емансипація одиничного приєднується до його суспільного визначення. Самовизначення - це суспільне завдання. Категоричний імператив приєднує індивідуальну максиму дії до Загального. При цьому важливо, що це Загальне ніколи не буває дійсним Загальним, а лише можливим. Дійсне Загальне не встояло б перед підозрою бути тотальним Абсолютним, якому мав би підпорядковуватись одиничний. Цей закид, зроблений критичною теорією, а також французькою філософією XX століття, зокрема Жілем Дельозом, є безгрунтовним. Можливе загальне $є$ завданням, завданням мислити загальне і особливе у єдності і від-

${ }^{1}$ Johann Baptist Schad's, Russisch-Kaiserlichen Collegienrathes und Professors der Philosophie in Jena, ehemals Benedictiners zu Kloster Banz, Lebensgeschichte, von ihm selbst beschrieben. Erster Band. Neue, durchaus umgearbeitete, mit Reflexionen über die, in unsern Tagen besonders interessanten, Gegenstände begleitete Auflage. Altenburg 1828, VI.

2 a.a. O. VII

${ }^{3}$ a.a.O. XI 
окремлено з метою, щоб не розпадались теорія і практика і щоб людина не підпорядковувалась нав'язаними їй чужим цілям.

Освітні зусилля сучасності мало спільного мають з ідеями Канта, Фіхте і Шада. Вони радше покладаються на те, що технічні поступи задаватимуть цілі із самих себе. Але що це буде за поступ, якщо ми не знатиме його цілей, його мету? Безперечно, було б нечесно і навіть хибно попросту ігнорувати завдання, пов'язані з технічним світом. Також не можна досягти успіху, якщо у пошуках протиотрути покладатись на старі концепції німецьких класиків. Але освіта, якщо дотримуватись її засадничих принципів, повинна тримати у полі зору цілісну людину. Тим не менш неприпустимо недооцінювати важливість створення умов для молодих людей, щоб вони були в стані працювати у дигітальному світі. Бути компетентним і застосовувати дигітальні медіа само по собі не $\epsilon$ поганим. Але буде обмеженням вбачати у цьому мету емансипаторських спрямувань. Так само часто недооцінюється відмінність між користуванням смартфоном, програмами для написання текстів та програмуванням. В останні роки дослідження у галузі освіти зробили значний внесок до приросту емпіричного знання, але з поля зору зникла жива дискусія щодо інструменталізації людини в економічних процесах капіталістичного господарювання. Потужні зусилля, спрямовані на те, щоб мобілізувати найманих працівників і зробити їх більш гнучкими, змушує забути про сенс витрат на навчання упродовж життя або всеохоплюючої дигіталізації. Намагання пристосуватись до поступу замовчує питання, яку мету, яку ціль має переслідувати поступ.Технічний поступ сам по собі не може здійснити емансипацію людини. Техніка нейтральна по відношенню до покладання цінностей у суспільстві, яке все ще складається з людей. На що здатна техніка, вже дуже переконливо показали останні сто років. Про це не слід забувати, мріючи про чудовий дигітальний світ. На його чудову поверхню накладається також й видимість. Водночас на цій поверхні з'являється і водночас приховується сутність. Водночас у заможних регіонах світу розпочався контр-рух. Його гаслом $€$ дигітальний детокс. Пропонується взяти відпуску або тримати дистанцію від перевантаження і завищеного темпу, заданого дигіталізацією, вимагається уповільнення, slowfood. Але це також водить в оману. Як показали Фіхте і Шад, тут має йтись передусім про те, щоб існувати у живий спосіб, бути присутнім в екзистенції, залишатись при собі, бути здатним до осмислювання, користуючись усією своєю усією чуттєвістю, розумом і розсудком , щоб самому не перетворюватись на засіб для чужих цілей. Отже, Фіхте застерігає: «Справжнє самозречення людини відбувається тоді, коли вона сама робить з себе засіб для чогось тимчасового та минаючого і спрямовує свою турботу тазусилля на щось інше, а не на не на неминуще і вічне. Приймаючи це до уваги, кожний повинен 
бути гідним самого себе і святим для самого себе. ...» (Fichte, 1845: 388). Таке вічне і неминуче не є метафізичною трансценденцією, бо це - «Я», яке має триматись у концентрованій рефлексії. Це джерело самовизначення і автономії, це джерело моральності. Людина не може їх втратити, не заперечуючи у собі людство.

\section{References}

Fichte J.G. (1845) Über das Wesen des Gelehrten und seine Erscheinungen im Gebiete der Freiheit. In: Fichtes sämtliche Werke. Bd.6. Hrs. von J.H. Fichte. 1845. S. 349-447.

\section{Christoph Asmuth. J. G. Fichte and J. B. Schad: education as a task}

The lecture is devoted to the explication of the functional possibility of education conceptualized as a task, which is addressed both to human and society. The problems concentrated on this field are regarded in the contemporary social and cultural contexts which the philosophyof education of Fichte and Schad would be proofed on its actuality. The connection between the politics and education are unveiled with their contextual and historical distinctions. The new tendencies of the developments of education are analyzed with positive and negative consequences both of the digitalization and ofthe empirical turn in the theory and practice of education. It is showed that the one-sided interpretation of the possibilities of the digital technologies is caused of the biological and pragmatically approaches to human being provoked of the radical changes in culture and in the world of labour. The positions of human both in the post-industrial reality and in the first decades of the XIX century have some common features because in those periods many new possibilities were opened for human's self-realization and perfection. Taking into account these circumstances the representatives of German idealism have paid especially much attention to education. For German idealism it is typically that the educational problems are regarded in connection with the idea of the freedom and the principal new conceptualization of human as a self-responsible person with no needs of the support from the higher metaphysical instances. The senses and functional potential of Kant's categorical imperative are analyzed on its anthropological foundation. The human is showed there in his affiliation to mankind, what means the self-obligationfor him and for the mankind. This would be obligate foundation of the all moral acts despite any kind of the heteronomy. All these ideas became the further development in Fichte and Schad. They state, that the human being must be defined with the taking into consideration the material substation of humanity. This assumption is necessary to clarify the importance of the human disposition for forming, what presumes available the human competence for using sensuality, reason and mind in problems solving in order not to turn into the instrument for purposesof the Others. This is the main and actual task of the education. 
Key words: education, German idealism, human, humanity, freedom, morality, organic body,digitalization.

\section{Кристофб Асмут. Харьковские лекции. Й.Г.Фихте и Й. Б. Шад: об- разование как задача.}

В лекции обосновывается целесообразность концептуализации образования как задачи, адресованной человеку и обществу. Связанная с этим проблематика рассматривается в современных социокультурных контекстах, где актуализируются философско-образовательные идеи Фихте и Шада, устанавливаются контекстуальные, а также исторические особенности этого соотнесения. Раскрывается взаимосвязь между политикой и образованием в различных исторических и социокультурных констелляциях. Анализируются тенденции развития современного образования, положительные и отрицательные последствия дигитализации, а также эмпирического поворота в теории и практике образования. Обосновывается, что односторонняя интерпретация возможностей цифровых технологий обусловлена биологизаторским и прагматичным пониманием человека, что является следствием радикальных изменений в культуре и сфере занятости. Положение человека в постиндустриальных реалиях и в начале XIX-го века имеет общие черты, обусловленные открытием новых возможностей его самореализации. Исходя из этого, представители немецкого идеализма особое внимание уделяли образованию. Проблематика образования в немецком идеализме тесно связана с идеей свободы и принципиально новым пониманием человека, который отвечает сам за себя, а не полагается на метафизическую надстройку. Анализируются смыслы и функциональный потенциал категорического императива Канта, его антропологические основания, где человек рассматривается в его единстве с человечеством, беря на себя обязательства перед собою и человечеством. Эти идеи получили дальнейшее развитие у Фихте и Шада. Они рассматривают возможности переноса проблематики свободы из теоретической в практическую плоскость. Для того, чтобы свобода стала реальностью, человек должен быть способным действовать в материальном мире, предпосылкой этого является наличие органического тела, способного к формированию. Фихте и Шад считали, что человек должен относиться к себе как к живому существу, он обязан быть самим собой и включать в процесс осмысливания всю свою чувственность, разум и рассудок, чтобы не превратиться в средство для достижения чужих целей.

Ключевые слова: образование, немецкий идеализм, человек, человечество, свобода, мораль, органическое тело, дигитализация. 


\section{Обговорення лекції К.Асмута на семінарі (Харківський національний педагогічний університет ім. Г.С.Сковороди):}

I. Ф. Прокопенко, ректор ХНПУ імені Г.С. Сковороди, доктор педагогічних наук, професор, академік НАПНУ. Ідеї німецького ідеалізму і nidготовка майбутніх педагогів.

Ідеї Фіхте і Шада укорінились на наших теренах, на грунті, підготовленому Г.С. Сковородою, але треба постійно повертатись до цих джерел. Для формування сучасного учителя надзвичайно важливе значення має філософська культура. Цьому моменту в Україні приділяється недостатньо уваги. Мене особливо непокоїть той факт, що у педагогічних університетах згортаються курси з історії філософії. Розуміння того, що освіта $\epsilon$ не просто культурним або соціальним капіталом чи символом статусу, або ще гірше - брендом, а передусім життєвим завданням кожного, щоб реалізувати свої зобов'язання перед людством, має стати орієнтиром сучасної педагогічної освіти.

М.Д. Култаєва, докт. філос. н., професор, член-кор. НАПНУ. Проблематика оновлення у німецькому ідеалізмі: екзистенціальна зустріч у просторі сучасності.

Проблематика свободи як оновлення $\epsilon$ наскрізною у німецькому ідеалізмі. Кант, Фіхте, Шад і Гегель зробили величезний внесок до укорінення цієї ідеї у свідомості сучасних суспільств, надаючи абстрактним утопіям тих рис, які були на часі упродовж їхнього життя, але також у перспективі бажаного майбутнього. Ніхто краще за Фіхте не обгрунтував взаємозв'язок між людиною і людством у здійсненні самопокладеної програми оновлення. Як приклад тут можна навести його «Промови до німецької нації», дух і запал яких $є$ надзвичайно актуальним для сучасної України, бо усі ми занадто довго блукали у лабіринтах відчуженого духа, не наважаючись визнати існування вітчизняних Мінотаврів, створених нами самими з будівельного матеріалу відчуженого духа. Оновлення суспільств, особливо духовне, ніколи не буває швидким і безболісним, а головне - одноколійним. Адже обмін колективістської свідомості на споживацьку також $є$ оновленням, але зі знаком мінус, бо тут відсутня наявність навіть натяку на мету людства. Те ж саме спостерігається у самовизначенні так званої «інноваційної людини», яка залюбки робить селфі, де відчужене від людства Я випростовується на тлі засвічених океанів або над завалами іншого непотребу. Отже духовне оновлення потребує філософського, психологічного і педагогічного супроводу. Гуманістично орієнтована стратегія оновлення і кроки у цьому напрямку, ба, навіть наміри почати рух у цьому напрямку супроводжуються амбівалентними реакціями, які коливаються від ентузіазму і піднесення до фрустрації, апатії або ж - гніву і спротиву. Але домінантним 
залишається соціальний і педагогічний оптимізм, притаманний модерним суспільствам, хоча у періоди інтенсивних соціальних і культурних трансформацій він поступається песимістичним настроям.

Варто зазначити, що євроінтеграційні прагнення українського суспільства, суперечності його духовного оновлення також спонукають звернутись до теоретичних конструктів західної філософської педагогіки класичного і пізнього Модерну з метою прояснення смислів європейської орієнтації, передусім це торкається відмінності між семантиками середньовічної та модерної Європи, а також сприяють з'ясуванню ролі педагогічної складової у європейській формі життя, яка в Україні розглядається здебільшого на емпіричному рівні або у площині застарілих онтологій, але конче потребує розгляду також і в філософсько-педагогічній площині, адже це є частиною посттоталітарних трансформацій.

В.В.Сагуйченко докт. філос. наук, професор, КЗВО «Дніпровська академія неперервної освіти». Німецький ідеалізм і завдання трансформування освітнього ландиафту України.

Ідеї німецького ідеалізму, їх порівняння із сучасністю є важливим моментом для більш чіткого уявлення щодо стратегій та актуальних завдань української освіти. Сьогодні ми є свідками, що незважаючи на нагальну потребу трансформації сучасної освіти, зусилля освітніх реформаторів наштовхуються на опір з боку певних структурних елементів освітніх і виховних систем і відповідних організацій. Ця тенденція спостерігається не тільки на пострадянському просторі, а й у розвинутих країнах Заходу, де субкультура інформаційного суспільства розвивається більш прискореними темпами, впливаючи на сучасну культуру в цілому. В українських національних контекстах окреслена тенденція має загрозливий характер і потребує термінових заходів. Імпульси, що походять з філософсько-освітніх праць Фіхте і Шада, безперечно, сприятимуть гуманізації вітчизняної освіти. Ризики втрати перспективи людини і людства у гонитві за оновленнями є реальними. Ця перспектива $є$ надзвичайно важливою у реформування системи освіти, змін культурного і освітнього ландшафту України. При цьому освітні інституції необхідно розглядати як структури, які утворюють каркас системи освіти на різних рівнях її функціювання. Суттєвим $є$ те, що організаційними і культурними формами освітніх інституцій виступають освітні установи різного рівня, які $\epsilon$ відносно автономними і водночас системно пов'язаними між собою. Важливо розглядати освітні інституції не в статиці, а в динаміці, що дозволяє виділити зовнішню і внутрішню логіку їх трансформацій. Внутрішня логіка змін інституцій освіти і виховання формується через процедури саморефлекciї, які можна деталізувати, спираючись на методологічну програму теорії соціальних систем. Зовнішні чинники, що впливають на трансформа- 
ції освітніх інституцій, обумовлюються відповідними соціокультурними і політичними контекстами.

Подолання таких обмежень у сучасному філософсько-освітньому дискурсі здійснюється через залучення досвіду соціально-антропологічних і культурно-антропологічних концептуалізацій освітніх інституцій та їхнього функціонального потенціалу. Важливо, що оцінка людинотворчого потенціалу освітніх інституцій з позицій свободи надає поштовх їхнім трансформаціям у напрямку відкритості та демократизації, тим самим створюються умови для легітимації альтернативних організаційних форм освіти, де домінує вже їх власна логіка, яка узгоджується зі суспільною. Шкільна культура як культура окремої школи конституюється на перехресті реального, символічного та уявного. Шкільні культури створюють імідж і репутацію школи. Синергетичне злиття різних напрямів виховання $є$ засобом посилення виховного впливу на особистість, не порушуючи її свободи та автономії. Воно принципово відрізняється від комплексного підходу до виховання, де ідеологічні настанови забезпечували інтеграцію різних освітніх і виховних практик. Регулятивний конструкт ідеальної комунікативної спільноти, орієнтує агентів та адресатів освітніх і виховних дій на досягнення консенсусу у розумінні перспектив розбудови освітніх інституцій, що є важливим для практичного впровадження концепції Нової Української школи.

В.О.Абашнік, докт. філос. н., професор ХНУ імені В. Каразіна. Iсторія життя Й. Б. Шада: досвід опрацювання життєвих та освітніх завдань.

Упродовж багатьох років я працюю над цією проблематикою і мої власні дослідження багато у чому збігаються з позицією професора Крістофа Асмута. Але я хочу звернути увагу на необхідність більш широкого залучення біографічного методу при залученні історико-філософського матеріалу до освітніх і виховних практик в Україні. Уся література, дотична до цієї проблематики, міститься у моїй монографії (Абашник В.А. Харьковская университетская философия (1804-1920). Харьков, 2014), де наводиться також детальна бібліографія праць Шада та інших німецьких професорів, які працювали у Харкові, створюючи зразки європейської форми життя на теренах Слобожанщини.

Н.В.Радіонова, докт. філос. наук, професор, директор інституту Г.С. Сковороди при ХНПУ імені Г. С. Сковороди. Ідеї німецького ідеалізму у структуруванні освітнього простору на Слобожанщині.

Я приєднуюсь до виступу проф. В.О. Абашніка. I хочу вказати на латентний зв'язок між сковородинівської традицією та німецьким ідеалізмом. Стиль мислення Г.Сковороди багато у чому нагадує стиль мислення 
Фіхте. Я маю на увазі передусім акцентування відповідальної свободи, яку відстоював Г.С. Сковорода.

Н.П.Шепітько, аспірантка кафедри філософії ХНПУ імені Г.С. Сковороди. Філософсько-освітні імперативи Г.С. Сковороди.

Я підтримую думку попередніх доповідачів і хочу зазначити, що сковородинівська етика і філософія виховання відкриває канали для сприйняття евристично насичених ідей німецького ідеалізму. Ця етика конче потребує нового прочитання у сучасних соціокультурних контекстах.

Ю.Ю. Кобзєва, аспірантка кафедри філософії ХНПУ імені Г.С. Сковороди. Німецький ідеалізм і філософбська есеїстка.

Розглядаючи філософські ідеї і внесок Фіхте і Шада до сучасної культури, варто звернути увагу, що німецький ідеалізм надав потужного поштовху для філософської есеїстки, яка свою чергу надає потужного поштовху для самовиховання людини. Зараз цей жанр занепадає. Він потребує підтримки, щоб вистояти у боротьбі зі спокусами глянцевого кітчу, який дезорієнтує молодь, вказує хибні шляхи для її самореалізації, а також цілком ігнорує оптику людства.

Крістоф Асмут, доктор філософії, професор філософії Технічного університету Берліну (ФРН). Керівник дослідницької групи «Трансцендентальна філософія - німецький ідеалізм», член наукових рад часопису «Фіхте-Штудії» та «Центру досліджень німецької класичної філософії» (Сорбонна), член різних міжнародних товариств, зокрема Міжнародного товариства імені Й.Г. Фіхте, почесний доктор Харківського національного педагогічного університету імені Г. С. Сковороди. Основні напрямки досліджень: трансцендентальна філософія, філософія мови, практична філософія, теорія пізнання.

Основні монографії: «Охоплення того, що неможливо охопити. Філософія та релігія у Йоганна Готтліба Фіхте» (1995), «Інтерпретація - Трансформація. Картина Платона у Фіхте, Шеллінга, Гегеля, Шляйєрмахера і Шопенгауера та проблема легітимації історії філософії» (2006), «Суб'єкт та принцип. Філософія початку» (2017).

https://orcid.org/0000-0003-0362-0953

christoph.asmuth@mailbox.org

Cristoph Asmuth, professor of philosophy, Technical University of Berlin, honor doctor of the National Pedagogical University "H. S. Skoworoda", is internationally recognized for his works on German idealism, philosophy of science and culture. His research addresses a range of fieldsincluding education, semiotics, picturing and sport.

https://orcid.org/0000-0003-0362-0953

christoph.asmuth@mailbox.org 